Kohl: a Journal for Body and Gender Research

Vol. 2, No. 1 (Summer 2016)

\title{
Freedom is a Constant Struggle: Ferguson, Palestine, and the Foundations of a Movement by Angela Y. Davis
} Haymarket Books, 2016.

Roua Seghaier 
They say that freedom is a constant struggle They say that freedom is a constant crying

They say that freedom is a constant sorrow

They say that freedom is a constant moaning

They say freedom is a constant dying

Oh Lord, we've died so long

We must be free, we must be free. ${ }^{1}$

Adducing the old adage of actions speaking louder than words, Angela Yvonne Davis embodies radical citizenship, activist, and scholarly engagement through her history of anti-imperialist and feminist struggles. Once on the FBl's most wanted list, Davis continues to haunt the increasingly intricate authoritarian systems on a global level by her continuous commitment to the exercise of intersectionality. Her new book, Freedom is a Constant Struggle, borrows its title from a freedom song chanted in the Southern United States during the twentieth century freedom movement, and it speaks precisely of that, of the continuities rather than closures when it comes to the unfinished plights for freedom all over the world.

The book is an edited volume that includes three interviews with Angela Davis, conducted by Palestinian solidarity activist and one of the Russell Tribunal for Palestine coordinators, Frank Barat, over the year 2014. The remaining seven chapters are speeches Davis has given in universities in the U.S., Great Britain, and Turkey from 2013 to 2015. Throughout the book, Davis urges the reader to think together about things that seem to be distinct and isolated, and to disaggregate things that seem to organically go hand in hand (104). This is precisely what Davis does as she discusses racism, genocide, the prison industrial complex, and settler colonialism from a perspective of intersectionality.

One of the most thought-provoking, albeit alarming, arguments of the book is the observation that our collective relationship to history is flawed. Not only do we embrace institutional memories, but we do so at the expense of our own. Individual memories, Davis explains, are not nearly as long as institutional memories, and especially repressive ones (93). We hence trick ourselves into adapting to a history that is not our own, and into making misinformed decisions about a collective future. One aspect of this misinformation upon which we build our beliefs and actions is the linguistic interchangeability of words that are nowhere near being synonymous when we historicize. Non-surprisingly, notions such as "freedom movements" and "civil rights movements" in the U.S. are used interchangeably, yet with the official narrative favoring the latter. This reveals an interesting slippage between "freedom" and "civil rights," as if the only way to obtain freedom is through the existing framework of rights, and as if the era of radical revolutions is long gone. Certainly, this is no innocent gaffe. It rather serves the resilience of these same oppressive institutions. This also means that the struggle of Black people, once they have achieved those "civil rights," can be consigned to the past. This allows people to speak of a post-racial era, and to mistake the election of one man as the marker of the

\footnotetext{
${ }^{1}$ Davis cites the first fragment of the Freedom Song in the beginning of the $5^{\text {th }}$ Chapter. You can access the full lyrics on http://courses.education.illinois.edu/ci407ss/freedomconstantstruggle.html
} 
end of racism. In this context, another interesting historical omission is the general oblivion of the Ten Points Program of the Black Panther Party. People know of the existence of the Program, yet they are unaware of its content. Davis explains that the official US Democracy narrative considers these points to have achieved their closure, while in reality they are still on the agenda. They are not a matter of the past.

If we have a hard time grappling with history or acknowledging how we inhabit our histories, this trouble with history can also be seen in the way in which our current mass actions are subjected to a media process of becoming stale news (122).

Racism is still the status quo. It is being reproduced and complicated through the rhetoric of terrorism and counterterrorism. Terrorism is often presented by the media as exclusive to certain groups of color, while other notions such as "genocide" are reserved for Europeans. What happens to them is portrayed to exceed everything that Black people for instance have endured for centuries. And so we learn that the term genocide is reserved for particular conditions defined by UN convention on the Prevention and Punishment of the Crime of Genocide, adopted in the aftermath of fascism - a fascism that happened in Europe. Meanwhile, other groups that were and are subjected to crimes comparable in magnitude have to resist through a state of unacknowledged terror. This lack of recognition persists with universalistic statements and proclamations that bolster racism, such as "All Lives Matter."

Hence, the discrimination continues and targets specific groups through the rhetoric of terrorism. The label of terrorist, in the case of Assata Shakur and many others, serves to deter activism. Counterterrorism and counterinsurgency are not peace-building mechanisms. Along with incarceration and settler colonialism, the supply the system with disposable bodies. All of these resonate with the definition of slavery as they have the concept of death at their core - the state of not being acknowledged within one's ancestry. Yet, prison, in all its forms, is not only the new Jim Crow, but it also represents the increasing profitability of punishment, as well as the global strategy in dealing with people of color and the immigrants from the global south. Police brutality is but one aspect of a greater tactic that renders more youth disposable and that is part of a surplus population to be managed through imprisonment. The prison industrial complex is a self-feeding mechanism that continuously creates its subjects. In fact, twenty-five per cent of the world's imprisoned people serves as forage for vast prison corporations with global dimensions such as the G4S. They benefit from strategies intended to hide social problems that have been pushed under the rug since the era of slavery (65).

The institutional violence of prisons complements and extends the intimate violence of the family, the individual violence of battery, and sexual assault. We can see violence encouraged by prison institutions on multiple levels. Case in point, Trans* women are sent to male prisons in order for the patriarchal system to multiply and feed off of the sexism and misogyny. These practices reproduce oppression and deter the steps taken to counter it. For instance, shall the label "women" be merely enlarged to encompass different women and assimilate them into the term, the logic of incarceration would not change. For instance, even if Trans ${ }^{*}$ women were incarcerated in female prisons, the prison-industrial institution would remain unchallenged. It would simply adapt to a more liberal understanding of the term while keeping its politics towards disposable bodies. Such action neither defies the term's exclusivity nor the prison industrial complex. Access to the 
Bourgeois hetero-patriarchal circle is not a victory. Rather, it counters the efforts to produce radical and revolutionary results. Similarly, carceral feminism that calls for the criminalization of gender-based violence does the work of the state because it focuses on state violence and repression as a method to counter the heteropatriarchy. Sexual assault is not an individual idea, and the individual is not the aberration at hand.

The prison industrial complex is interested in producing legitimizing discourse. It is a profitable business that has nothing to do with justice. Darren Wilson, the police officer who shot Michael Brown in Ferguson, was trained in Israel, and so were the police officers who occupied Missouri after the shooting. Israel uses carceral technologies developed in relation to US prisons not only to control more than 8000 Palestinian political prisoners, but also the broader Palestinian population (108). The same tear gas canisters flown in Ferguson are flown towards Palestinian activist. Common injustice develops a symbiotic relationship of solidarity and inspiration. The Palestinians who noticed the equipment used to suppress Ferguson protests were tweeting advice to the U.S. activists. Also, Palestinians organized freedom rides similar to those of the 1960s by boarding segregated buses in occupied Palestine. While we might think of a certain distinct event in relation to struggle, protest, or revolution as a finality or as closure - a historical high point leading to an ultimate triumph of democracy - it is far from being so. Freedom is a [continuous] struggle, and shall we learn to differentiate between the "result" and the "impact" of dissent, we will embrace our struggles as collective and transnational, and we will see our freedom as incomplete if limited to a certain group.

Thus, international solidarity is not only possible, it is already showing signs of its emergence. Davis explains that the Ferguson movement has understood that it does not need the traditional charismatic Black male leadership. Without romanticizing the movement, she explains that agency shall not be limited to leaders, centering collectivity at the core of change instead. She draws upon her experiences, and does so humbly without epitomizing herself. She calls to disinvest from the messianic leadership notions, and to strategize, mobilize, and build consensus as part of participating in collective praxis. When different groups of people around the world protested the killing of Trayvon Martin or the imprisonment of Davis herself, they were not solely moved by the plight of these individuals, but by the injustices they face in their seemingly remote and unaffected geographical locations. The history of violence of European colonization, including slavery, has similar effects in Africa, Asia, the Middle East, and the American Hemisphere. By acknowledging these transnational solidarities and not deeming them as erratic and occasional, we can start understanding the roots of oppression globally. Only then can we emerge from our entrenchment in the neoliberal individualism of this era. 